\title{
舌弁使用による口蓋裂患者の口蓋瘻閉鎖法について
}

\author{
高橋庄二郎・重松知寛・大井基道・古沢正巳・川本黄石
}

\section{Closure of a palatal fistula in a cleft palate patient by the use of the tongue flap}

\author{
Shojiro Takahashi : Tomohiro Shigematsu $\cdot$ Motomichi OHI \\ Masami Furusawa $\cdot$ Koseki Kawamoto
}

\section{I. 緒}

\section{言}

一般に口蓋裂に対しては，良好な鼻咽腔閉鎖機能をも つ口蓋を形成して正常な言語楼能を獲得させるため, 口 蓋後方移動術が広く行われている. しかし，口蓋の後方 移動を十分に行えば行うほど，口蓋前方部に鼻口腔瘦を きたしやすい.とくに最近では Manchester 法ないし Cronin 法1), Millard の island flap 法2-5) などが多く の人々に用いられるよらになったが，これらの方法では さらに口蓋瘦を形成しやすいものと考えられる.

口蓋形成術後にみられる硬口蓋前方部の比較的小さな 掼は, 瘦周囲の口蓋粘膜弁や敬唇移行部付近からの粘膜 升をもって容易に閉鎖することができるが，やや大きな 掼では, 瘦周囲の症痕化ないし fibrosis のため, 前述の 方法では弁の壊死をきたして閉鎖に失敗することが多い. 最近 Guerrero-Santos ら $\left(1964^{6)}, 1966^{7)}\right)$ は舌弁を用 いる口蓋瘦の閉鎖法を発表し, Jackson ${ }^{8) 9}(1972)$ も同様 の手術を試み, 安全確実な方法として舌我の利用を推賞 している．私たちも，口蓋形成術後中等度の大きさの口 蓋瘦をもつ口蓋裂患者に対して舌弁を用いる瘦閉鎖を行 い，良好な結果をえたので，本手術法の概要について報 告する.

\section{II. 手術の術式と症例}

手術は 2 つの有茎弁の使用からなる. その 1 つは口蓋 から採取する弁で，鼻腔底を形成し，他の 1 つは舌背か ら採取する弁で，口蓋瘦の閉鎖と口腔側 raw areaの被

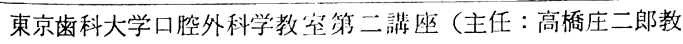
授)

Second Department of Oral Surgery, Tokyo Dental College

(Chief : Prof. Shojiro Takahashi)

受付 昭和 48 年 10 月 29 日
㠅を計る。

手術はまず瘦後方の口蓋粘膜から，前方に基部をもつ hinge flap を作り（写真 1-A）、これを反転して瘦前方 に形成した小さな有茎弁と縫合し，鼻腔底を作る（写真 1-B). ついで，舌背中央部から幅約 $2 \mathrm{~cm}$, 長さ約 $4 \mathrm{~cm}$ の舌尖部に基部をもつ有茎弁を採取するが（写真 1-C, D)，この舌弁の基部は舌尖より約 $1 \mathrm{~cm}$ の部位に扰く. 舌升採取部は粘膜下剥離によって容易に一次閉鎖できる が，後方端ではY字縫合を行う（写真 1-D). 舌弁反転 による口蓋瘦閉鎖と口蓋弁採取部の被覆に先立って，瘦 側方部の軟組織を一部切除しておく， 口蓋への舌弁縫合 は, 最初口蓋弁採取部最後方端に行い，ついで側方およ び前方の口蓋粘膜とやや細かに縫合する. 最後に, 術後 の舌運動を制限して舌弁の確実な生着を計るため, 雨側 舌尖部に太目の縫合糸または細い金属線を通し，これを 上顎歯牙に固定して括く（写真 1-E).

舌弁の切離は第 1 次手術後10日ないし14日で行5. 舌 弁の最後方部はしばしば口蓋から剥離しているので, 舌 我切離は基部付近で行う。第 1 次手術後には, 軽度の燕 下障害と言語障害をきたすが，必ずしも胃栄養管を使用 する必要はない。

写真 2 は，37才女子の両側唇䫟口蓋裂患者で，push back method による口蓋形成術後な扰 premaxilla 後方 にやや大きな口蓋瘦を有するものである（写真 2-A）. 舌弁使用による瘦閉鎖後汇は，飲食物の鼻腔内流入は全 くなくなり，言語障害も改善され，患者の精神的苦痛も かなり軽隇させることができる，本例では，舌弁固定に ナイロン系を用いたが数日でこれが離断し，舌弁後方部 が口蓋から 1 部虽離した. 移植組織は 2 カ月後でも鮮紅 色を呈し，舌乳頭の消失がみられなかった（写真 2-B）. なお舌の運動障害や朱覚障害は全くみられず，形態の異 常も発現しなかった（写真 2-C). 


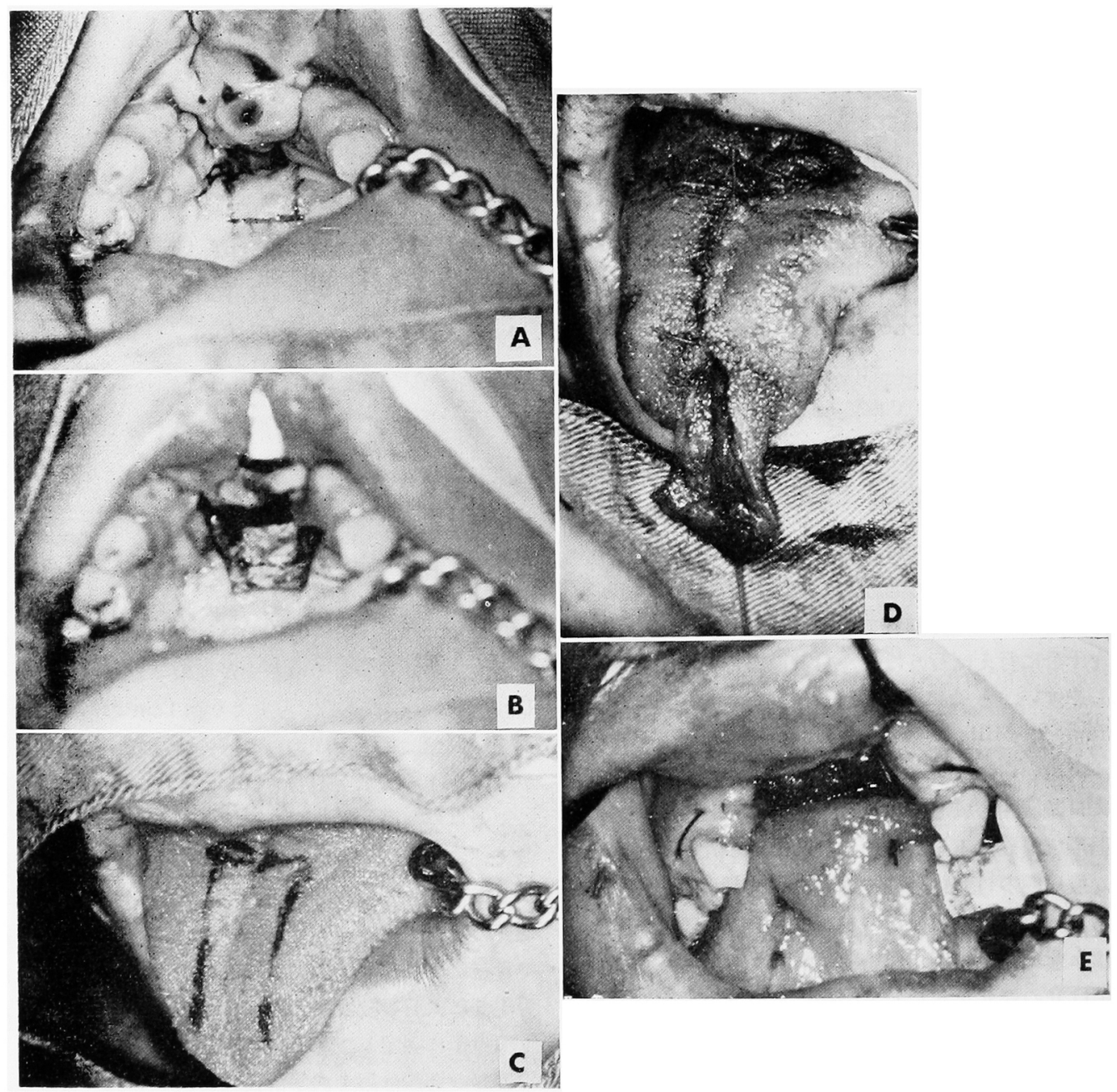

写真 1 舌弁による硬口咀燃閣鎖手術
A. hinge flap 形成のための切開線
B. hinge flap による奥腔面被覆
C. 舌升形成のための切開線
D. 手の形成
E. 舌弁炕よる口腔倒 raw surface の被覆

写真 3 は，33才男子の左侧唇顠口蓋裂患者で, island flap を用いる口蓋形成術後，硬口蓋前方部に瘦をきたし， 口镸第 2 次修正術時に口唇粘膜弁を用いて䫇裂部と口蓋 掼の閉鎖を計ったが，口蓋癄の完全閉鎖ができなかった 症例である（写真 3-A）。蓋震は比較的小さかったが, 瘦周囲の fibrosis が著明なため舌弁による缯閉鎖を行っ た（写真 3-B）. 本例では舌固定に細い金属線を用いた。 写真 4 は，23才女子の左側唇顎口蓋裂患者で，他院で 口盐形成衍を受けたるのである，漼周国の口蓋粘膜弁を 用いて磨の閉鎖を計ったが，弁の堎死をきたしたため，
舌弁による閉鎖手術を行った。

III. 考察

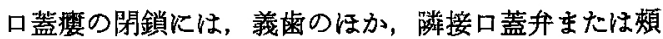
粘膜弁，舌少，中間層植皮を用いる鼻中隔升，煩手また は舉唇弁，腹部，腕部，頸部，前頭部からの筒状升など

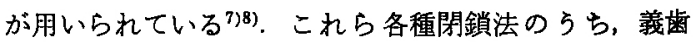
は，永久的なるのではなく，とくに图牙の欠損が多い場 合には，義幽の維持安定性が著しく悪くなる．隣接粘膜 弁を用いる力法は最も簡単であるが，口蓋形成術後の掼 

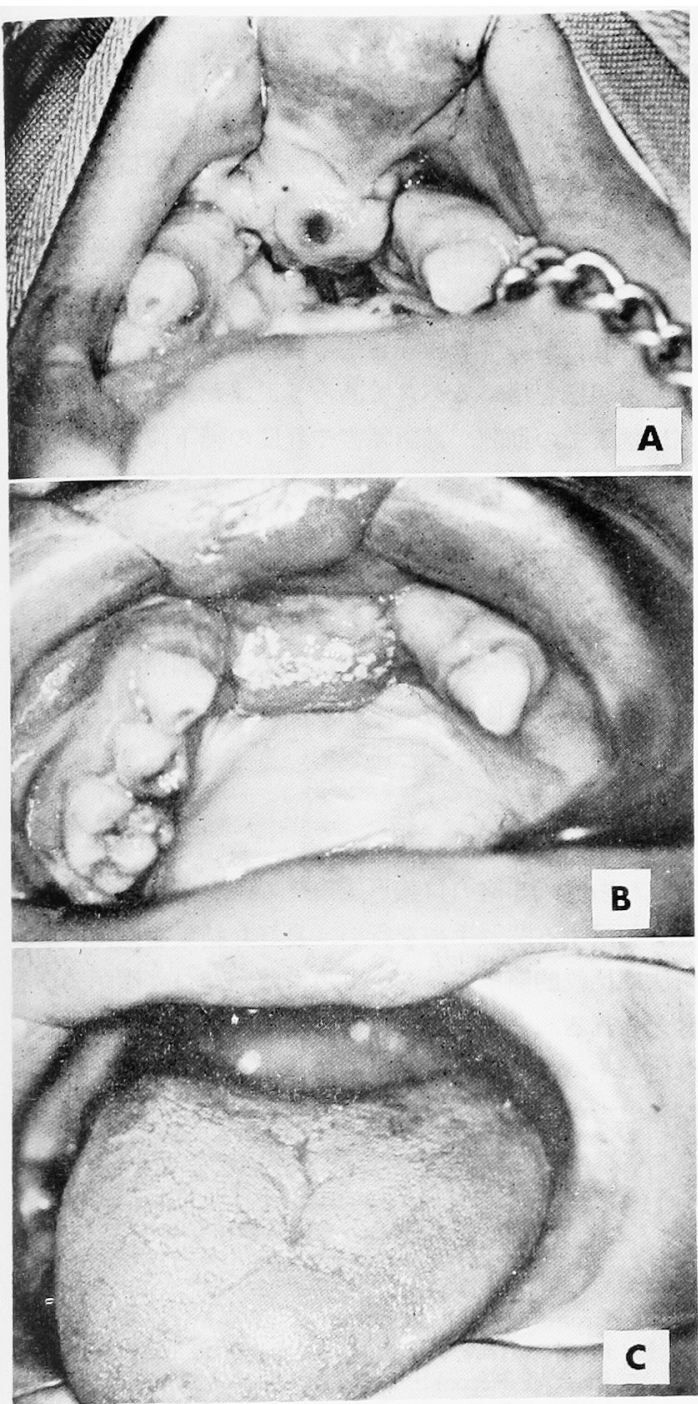

写真 2 症例 1.37 才女子両側辰䫇口蓝裂
A. やや大きな口蓋瘁
B. 舌弁迈閉鎖 2 力月後の所見
C. 術後 2 力月目の舌所見

周囲には瀦痕化組織が多いので，小さな瘦以外では閉鎖 に失敗することが少なくない，舌弁を利用する口蓋敬閉 鎖手術は，完全治痖江至る日数が比較的短く，顔面その 他皮膚部に損傷をきたすこともないむた舌は血管の分 布が豊富なため移植組織が壊死に陥ることがなく，最も 安全確実な瘦閉鎖法であると考方られる。

Guerrero-Santos 57は, 水癌, 除創, 腫瘍, 口蓋裂 などよる硬口蓋震10例に対して舌势を用いる閉鎖手 術を行い，本法の容易性と確実性を強調した。しかし Guerrero-Santos らは, 最初の 2 例では舌固定を行わな
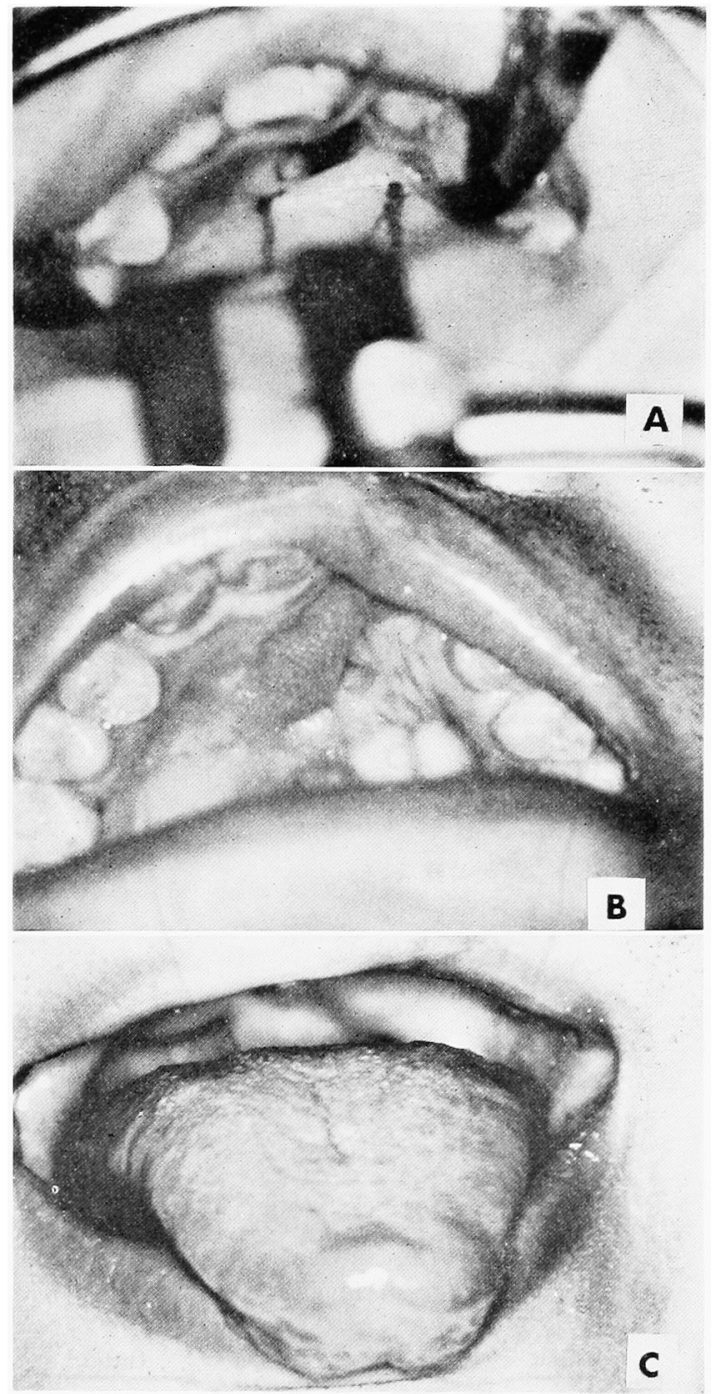

写真 3 症例 2.33才男子の左倒唇䞄口蓋裂
A. 術前所見
B. 術後 2 力月目の口蓋所見
C. 術後 2 力月目の舌所見

かったため， 、蓋から舌弁の虽離をきたしたことから， 舌弁の口唇ま大は歯牙への固定が重要であると述べてい る. Jackson ${ }^{8)}$ \& 4 例の口蓋㾯閉鎖炕舌弁を用いている が，彼は舌の固定は必要なく，第 2 次手術に拉いて舌弁 を延長して切離し，瘦後方部を閉鎖することができると 述べている. しかし，私たちは舌升生着のための舌固定， とくに金属線による歯牙への固定が必要であると考えて いる.

な扮, Conley $5^{10)}(1957)$ ，Bakamjian $\left.{ }^{11}\right)(1964)$ は扁 桃部および後田场詞の組織欠損被覆に舌からの有茎弁を, 


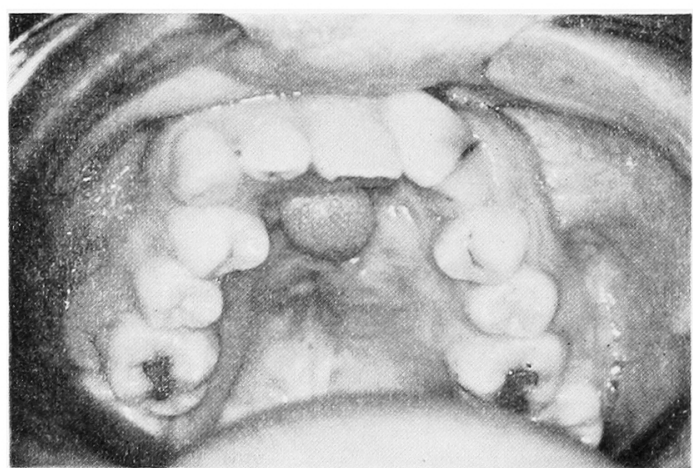

写真 4 症例 3. 23才女子左側唇影口蓋裂舌弁 による口蓋㵂閉鎖後 2 カ月目の所見

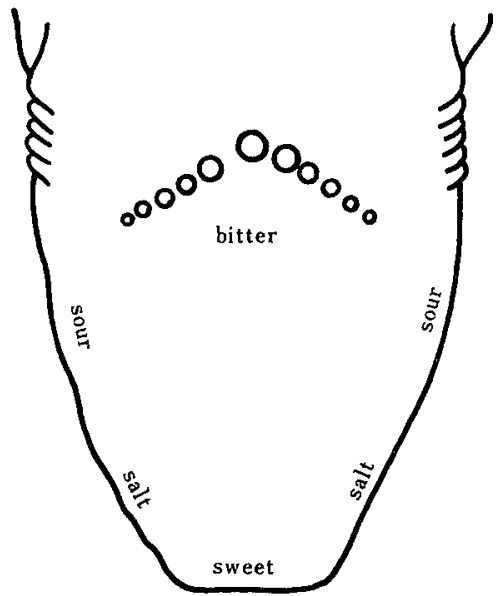

図 1. 各種味覚の感受性が高い部位 (Moncrieff)

Edge of tongue

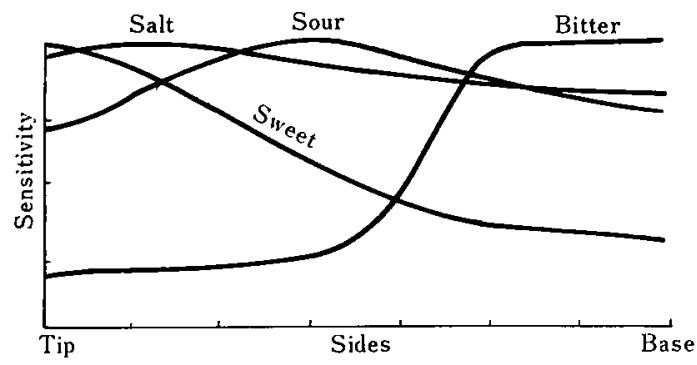

图 2. 舌侧縁の味覚感受性 (Hänig)

Bakamjian $^{11)}$ (1964), Guerrero-Santos 56) (1964), McGregor ${ }^{12)}(1966)$ ，Jackson ${ }^{9}$ (1972) などは口唇赤唇部 の欠損修復に舌弁を用いている.

舌に扣ける味覚感受性は，图1扎よび2に示すごとく， 舌側緑において高く，乙か子部位によって味覚の種類が

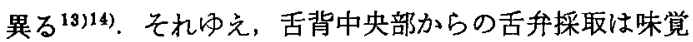

をほとんど障害しないるのと考えられる。私たちは、甘 味感受性の低下を防ぐため舌尖部からの組織切除をさけ た. Jackson ${ }^{8) 9}$ は，舌背からの舌弁採取は舌幅径の $2 / 3$ まで可能で，必要によっては採取部に中間㬝植皮を行う と述べている。

一般に移植組織は，きわめて長期間にわたって解紅色 を呈して舌乳頭は消失せず，周囲組織と異った状態を呈 する. したがって口唇赤唇部の再建には，できる限り舌 下面の組織を用いるべきであるう。また本手術は，弁基 部切離までの期間，言語障害や軽度の與下障害をきたす ので，幼小児への適応は困難であり，弁基部切離時には 全身麻醉を用いることがむずかしい欠点がある。しかし 舌弁採取後，舌運動の障害は全くみられず，著しく大き な弁を採取しない限り，舌の形態異常むあらわれない。 な标，Guerrero-Santos $5^{6)}$ は，第 1 次咽頭弁移植術を 用いる口蓋後方移動術や，顎裂部への第 2 次骨移植術時 にも舌弁を利用できると述べている。

\section{IV. 結}

論

私たちは，3 例の口蓋形成術後の硬口蓋瘦に対して舌 升を利用する閉鎖手術を行い，良好な結果をえた。本手 術法は比較的簡単で，しかも最も確実な口蓋掼閉鎖法と 考えられる、とくに隣接口蓋粘膜による瘦閉鎖に失敗し た症例や，须智正後などにみられる，中ゃ大きな口蓋瘦 閉鎖に有効である.

本論文の要旨は第 17 回日本口腔外科学会総会（昭和 47 年 10 月 7 日)に拉て発表した。

$$
\text { 文献 }
$$

1) Cronin, T.D. : Method of preventing raw area on nasal surface of soft palate in push back surgery. Plast \& Reconstr Surg $20: 474-4821957$.

2) Millard, D. R. : Wide and or short cleft palate. Plast \& Reconstr Surg 29:40 57 1962.

3) Millard, D.R. : The island flap in cleft palate surgery. Surg Gynec \& Obst 116:297-300 1963.

4) Millard, D.R. : A new use of the island flap in wide palate clefts. Plast \& Reconstr Surg $38: 330$ 3351966.

5）高橋庄二郎，他：Island flap を用いる口蓋挠方移動術炕 ついて. 日口外誌 $16: 13-171970$.

6) Guerrero-Santos, J., Vazquez-Pallares, R., Vera, A., Machain, P., and Castaneda, A. : Tongue flap in reconstruction of the lip. In Transactions of The Third International Congress of Plastic Surgeons Excerpta Medica Foundation. Amsterdam, 1964, p, 1055

7) Guerrero-Santos, J. and Altamirano, J.T. : The use of lingual flaps in repair of fistulas of the hard palate. Plast \& Reconster Surg 38: 123-128 1966.

8) Jackson, I.T. : Closure of secondary palatal fistulae with intra-oral tissue and bone grafting. Brit $\mathrm{J}$ 
Plast Surg 25 : 93-105 1972.

9) Jackson, I.T. : Use of tongue haps to resurface lip defects and close palatal fistulae in children. Plast \& Reconstr Surg 49:537-541 1972.

10) Conley, J.J. Amesti, F., Pieree, M.K. : The use of tongue flaps in head and neck surgery. Surgery $41: 745-7511957$.

11) Bakamjian, V.: Use of tongue flaps in lower-lip reconstruction. Brit J Plast Surg 17 : 76-87 1964.
12) McGregor, I. A. : The tongue flap in lip surgery. Brit J Plast Surg 19:253-263 1966.

13) Moncrieff, R.W.: The Chemical Senses. Leonard Hill, London, 1944, p. 65.

14) Hänig, D.P. : Zur Psychophysik des Geschmacksinnes. Philos Stud $17: 576-623$ 1901. Geldard, F.A. . The Human Senses, John Wiley \& Sons, New York, 1953. p. 305, より引用 